\title{
The North European Platform suture zone in Poland
}

\author{
Jan Golonka, Kaja Pietsch, Paweł Marzec \\ AGH University of Science and Technology, Faculty of Geology, Geophysics and Environmental Protection; \\ al. A. Mickiewicza 30,30-059 Krakow, Poland; e-mail: jgolonka@agh.edu.pl
}

(C) 2018 Authors. This is an open access publication, which can be used, distributed and reproduced in any medium according to the Creative Commons CC-BY 4.0 License requiring that the original work has been properly cited.

Received: 3 January 2018; accepted: 28 January 2018

\begin{abstract}
The authors interpret the structure of the Central Carpathian-North European plates suture zone in Poland, where three main Carpathian tectonic units: the Central Carpathian, Pieniny Klippen Belt (PKB) and Outer Carpathian are present. In general, the PKB follows this zone. Several deep bore-holes were drilled in this region and the seismic lines were tied to bore-hole data and geological maps. The Polish PKB belongs to the complex geological structure stretching from Vienna in Austria to Romania. The rocks included in the PKB tectonic components were deposited within the paleogeographic realm known as the Alpine Tethys, mainly during the Jurassic-Early Cretaceous times. Both strike-slip and thrust components occur within the Polish section of the PKB. The strongly tectonized, few kilometer wide PKB zone is limited by a flower structure marked by two major faults, linked to the strike-slip zone. These faults reach the North European Platform (part of the North European Plate).

The flysch sequences, arranged into a series of north-vergent thrust-sheets, constitute the main component of the PKB in the survey zone. They contain olistoliths, which are mainly Jurassic-Early Cretaceous in age. The PKB tectonic components of different age, strike-slip, thrust as well as toe-thrusts and olistostromes are mixed together, giving the present-day mélange character of this belt, where individual units are hard to distinguish. Two olistostrome belts (mélange units) exist within the PKB structure. The seismic lines show the Central Carpathian Paleogene rocks covering the Paleozoic Central Carpathian Basement south of the PKB. The Subtatric covers the High-Tatric autochthonic and allochthone rocks. The Central Carpathian Plate is thrust over the North European Platform in the Podhale region. The allochthonous Outer Carpathians consist of several nappes (thrust-sheets) verging northward. They are thrust over each other and over the North European Platform which dips gently southward.
\end{abstract}

Keywords: Carpathians, Pieniny Klippen Belt, North European Platform, seismics, tectonics, olistoliths

\section{INTRODUCTION}

The goal of this research was the interpretation of the Central Carpathian-North European plate suture zone in Poland. The authors utilized a deep seismic reflection survey in the Nowy Targ area. This survey is tied to the Zakopane-Kraków regional cross-section. Three main Carpathian tectonic units: Central Carpathians, Pieniny Klippen Belt (PKB) and Outer Carpathians are present in this area. Knowledge of the PKB structure in Poland was based on geological and geophysical surveys as well as on the deep drillings. The Deep Seismic sounding CELEBRATION 2000 revealed the existence of a suture between the Central (Inner Carpathians) (ALCAPA) and North European Platform (part of the North European Plate) (Grad et al. 2006, Środa et al. 2006, Janik et al. 2009, 2011, Hrubcová \& Środa 2015).

The following deep bore-holes: Bańska IG-1, Bańska PGP-1, Maruszyna IG-1, Nowy Targ PIG-1, Bukowina Tatrzańska PGP-1, Biały Dunajec PGP-2, Biały Dunajec PAN-1, were drilled in this region. Only one well - Maruszyna IG-1 - penetrated the 
PKB. The geological field work permits the claim that the PKB borders the Podhale Flysch (Inner Carpathian) to the south and the flysch of the Magura Nappe (Outer Carpathian) to the north. These borders have a tectonic character. The tectonic character of the contact is a subject of discussion. Some opinions consider the nappe character of $\mathrm{PKB}$, while others discuss the strike-slip flower structure or both features (e.g. Birkenmajer 1977, 1983, 1986, 1988, Jurewicz 2005, Golonka et al. 2005, 2015, 2016a, 2016b, 2017).

\section{GENERAL GEOLOGICAL OUTLINE}

The structure of the Central Carpathian-North European plate suture zone in Poland, is defined by
Central Carpathians, Pieniny Klippen Belt (PKB) and Outer Carpathians units (Golonka et al. 2005).

The Central Carpathian Paleozoic and Mesozoic rocks crop out in the Tatra Mountains south of Zakopane (Figs. 1, 2). North of the Tatras, in Poland, they are covered by the Podhale Flysch (Central Carpathian Paleogene) and known only from bore-holes and geophysical data (Golonka et al. 2005). The Central Carpathian Paleozoic is represented by granite and metamorphic rocks representing the Proto-Carpathians, finally shaped by the Variscan tectono-metamorphic events (Gawęda \& Golonka 2011). The bore-holes in the vicinity of the PKB did not reach this Paleozoic crystalline basement. They reached the Mesozoic sedimentary rocks, mainly carbonates.
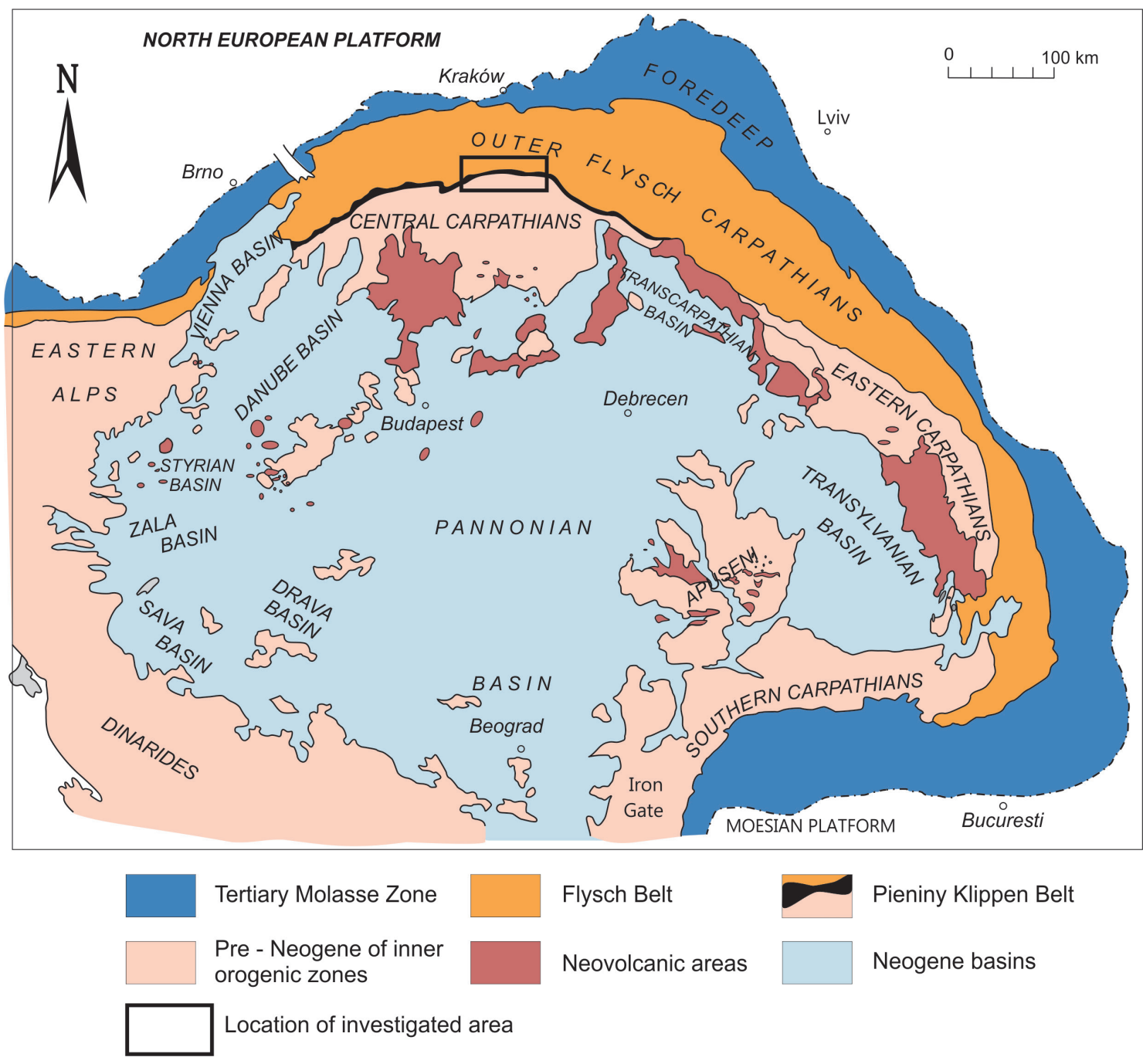

Fig. 1. Geological map of the Carpathians and adjacent areas with the location of investigated area (modified from Kováč et al. 1998, Golonka et al. 2011) 


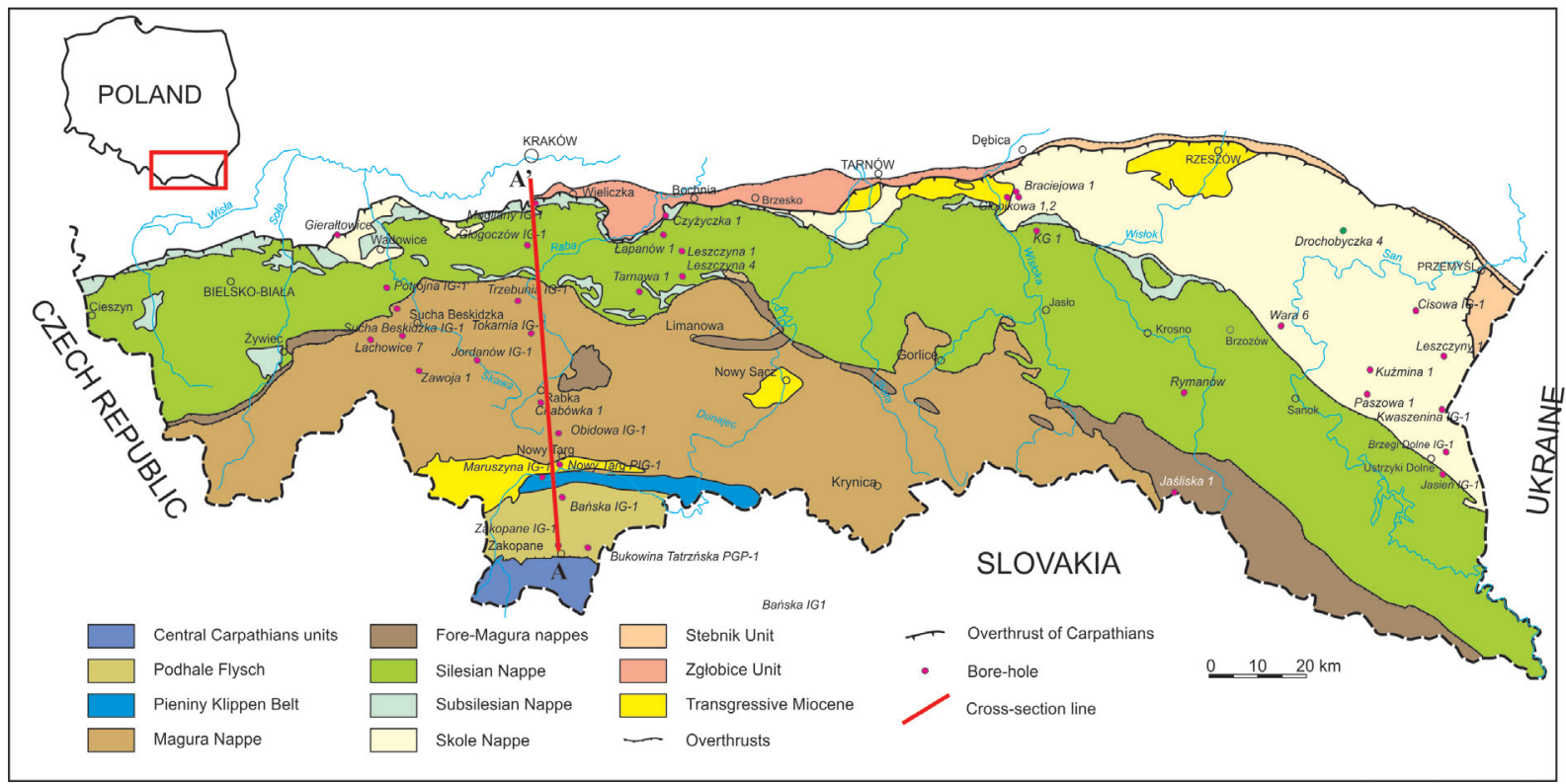

Fig. 2. Map of the northern part of the Outer Western Carpathians in Poland with the location of Zakopane-Kraków cross-section (A-A' in Figure 5). Compiled and modified from various sources (Ślaczka et al. 2006, Golonka et al. 2005, 2011)

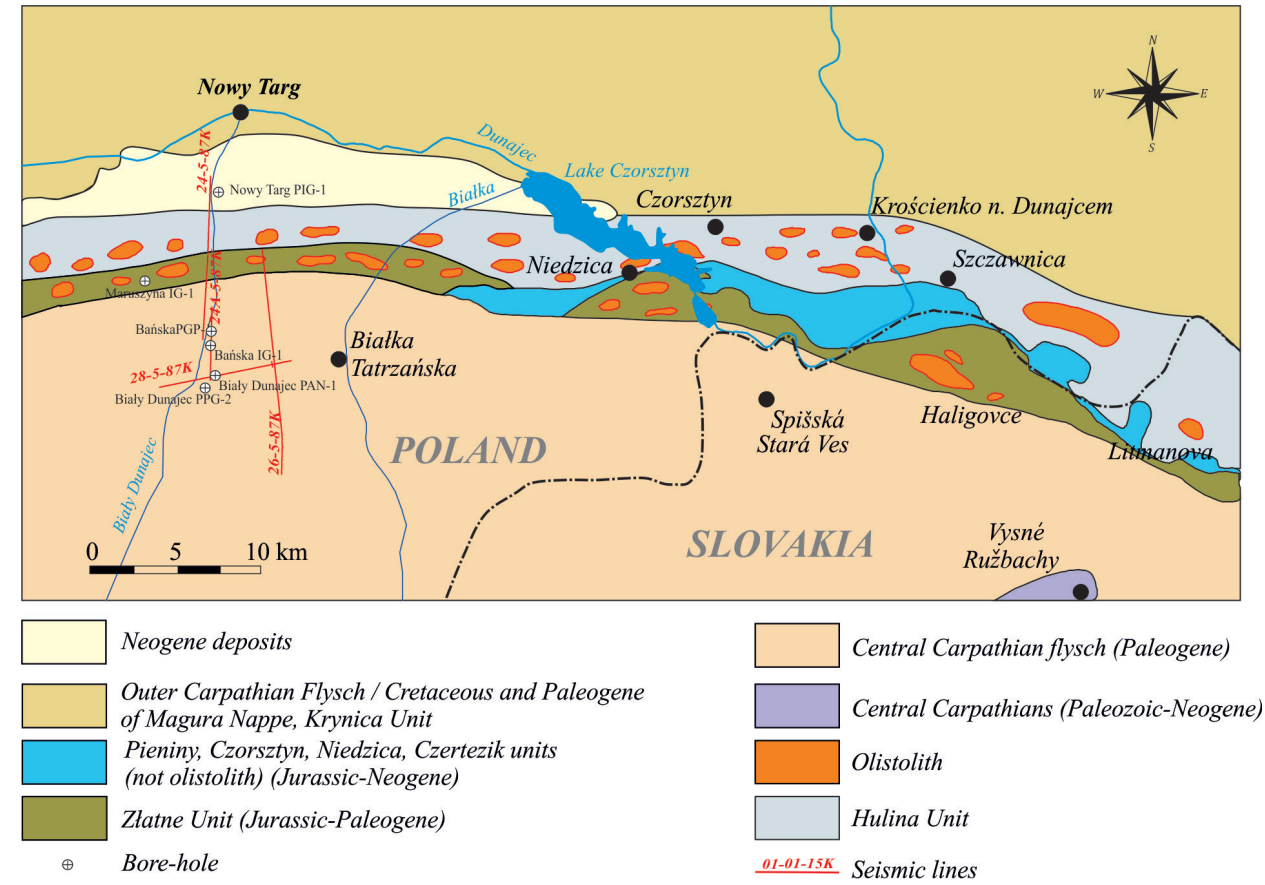

Fig. 3. Sketch map of the Pieniny Klippen Belt in Poland (modified from Golonka et al. 2015)

These rocks were assigned to the structural unit named after the bore-holes names as the Biały Dunajec and Bańska units, which were distinguished in the deep wells (Wieczorek \& Barbacki 1997, Chowaniec \& Kępińska 2003, Chowaniec 2009). The Mesozoic sedimentary rocks of the Tatra Mts. belong to the High-Tatric and Subtatric units
(Golonka et al. 2005 and references therein). The lowermost High-Tatric Unit includes the autochthon that is the sedimentary cover of the Paleozoic crystalline rocks as well as the allochthonous nappe. The Subtatric Unit can be divided into the Lower, Middle and Upper Subtatric zones. These zones correspond to the Slovak (e.g. Mahel 1974) 
Central Carpathian Mesozoic nappes - Krížna, Choč and Strážov respectively. They occur exclusively in thrust sheets, which overlie the High-Tatric Unit. Both units include Triassic-Cretaceous sedimentary rocks, mainly carbonates. The units and zone classification was based on facies differences and the paleogeographic position. The allochthonous units are discordantly covered by a postnappe transgressive succession of the Paleogene
Podhale Flysch (Golonka et al. 2005). The Middle Eocene conglomerates and limestones form the basal member of the Podhale Paleogene. They are covered by typical flysch deposits, which reach ca. $3000 \mathrm{~m}$ in thickness.

The $40 \mathrm{~km}$ long Polish PKB (Figs. 2, 3) belongs to a complex geological structure, some $600 \mathrm{~km}$ long, 1-20 km wide, stretching from Vienna in Austria to northern Romania (Fig. 1).



ENVIRONMENT

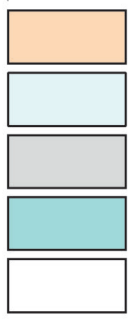

Topographic medium - low Shallow marine, shelf Slope Deep ocean basin with sediments Deep ocean basin with little to no sediments

\section{LITHOLOGY}

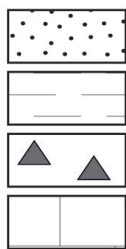

Sandstone, siltstone Shale, clay, mudstone

Biogenic siliceous deposit

Limestone
TECTONIC ELEMENTS



Oceanic spreading center and transform faults (black line) Active subduction zone

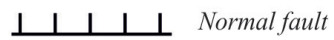

OTHERS

Present day coastline and suture

$+\quad$ Lat/long tics
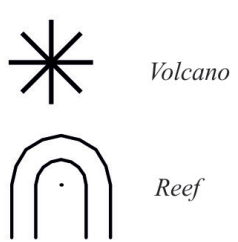

Reef

Fig. 4. Paleoenvironment and paleolithofacies with the main paleogeographical elements of the West Carpathians and adjacent areas during the Latest Jurassic-Early Cretaceous (from Golonka et al. 2011, modified). Plate position $140 \mathrm{Ma}$ 
The name "Pieniny Klippen Belt" was derived from the Pieniny Mountains - the mountain range in Poland. The term "Klippen" indicates erosion-resistant blocks, mainly limestones, which are surrounded by flysch sequences and marls (Golon$\mathrm{ka}$ et al. 2015). They form distinctive morphological features (cliffs). The sedimentary rocks of the PKB were deposited within two basins divided by the ridge (Golonka \& Krobicki 2004, Golonka et al. $2015,2017)$. These basins belonged to the paleogeographic realm known as the Alpine Tethys (Fig. 4). They were divided by the mid-oceanic Czorsztyn Ridge, which originated during the Bajocian (Golonka et al. 2015). The Czorsztyn succession was deposited on the highest part of the Czorsztyn Ridge and the transitional slope sequences below this succession are known as the Niedzica and Czertezik successions (Birkenmajer 1977, 1986, 1988).

Somewhat deeper sedimentary zones known as the Pieniny, Branisko and Zawiasy successions (Birkenmajer 1977, Golonka et al.2006b) were located on the ridge slope. The ridge and slope sequences are characterized by the presence of the Middle Jurassic-Lowest Cretaceous crinoidal, nodular (the Ammonitico Rosso type) or cherty (the Maiolica-Biancone type) limestones and radiolarites and the Upper Cretaceous pelagic marls (Birkenmajer 1977, 1988, Golonka \& Krobicki 2004). The extremely deep-water Jurassic-Lower Cretaceous pelagic limestones and radiolarites represent the older depositional sequences within the basins (Golonka \& Sikora 1981). Flysch sedimentation has prevailed in the basins since the Albian times. The Pieniny Klippen Belt originated 20-14 million years ago as the flower structure is limited by deeply rooted faults on both sides (Birkenmajer 1983, Ślączka et al. 2006, Golonka et al. 2010, Golonka \& Waśkowska 2014). Following its uplift, the Pieniny Klippen Belt obtained its present structure, which removed less competent rock complexes, leaving harder cliffs protruding and well visible against their background (Krobicki \& Golonka 2008).

North of the PKB, the Outer Carpathian is composed of a stack of nappes and thrust-sheets, which are thrust over the southern part of the North European Plate, covered by autochthonous Miocene deposits of the Carpathian Foredeep. These nappes are built up of up to $6 \mathrm{~km}$ of thick, continuous flysch sequences, representing the Jurassic through Early Miocene ages. These sequences are divided into the Magura Nappe, Fore-Magura group of nappes (units), Silesian Nappe, Subsilesian Nappe, and Skole (Skiba) Nappe (Golonka et al. 2005). The Magura Nappe represents the highest, southernmost unit occurring in front of the PKB. The following tectonic units have been distinguished within the Magura Nappe: the Krynica, Bystrzyca, Racza and Siary units (Ślączka et al. 2006). The Krynica Unit, which includes the Cretaceous-Miocene flysch is separated from the PKB in Poland and the adjacent part of Slovakia by a steeply southward dipping strike-slip boundary (Ślączka et al. 2006, Golonka et al. 2010, Golonka \& Waśkowska 2014). The highest peaks of the Gorce Mountains are built mainly of the thick-bedded sandstones of the Eocene-Oligocene Magura Formation - Poprad and Piwniczna Members. More shaly units of the Paleocene-Lower Eocene Szczawnica and Zarzecze formations occur in the Gorce slopes and Dunajec valley. The marine Miocene deposits occur in the western part of the investigated area next to the PKB (Kaczmarek et al. 2016).

\section{DATA AND METHODS}

The geological and geophysical data from deep bore-holes contained in the PiG-PIB Central Geological Database and in published papers (Paul \& Poprawa 1992, Wieczorek \& Barbacki 1997, Golonka et al. 2005, Chowaniec 2009, Birkenmajer \& Gedl 2012, Kaczmarek et al. 2016), seismic reflection profiles (Geofizyka Kraków SA and PGNiG databases) as well as the results of other geophysical investigations - Deep Seismic Survey (CELEBRATION 2000 project, particularly CEL04 seismic profile (Grad et al. 2006, Środa et al. 2006, Janik et al. 2009, 2011, Hrubcová \& Środa 2015), magnetotelluric survey (Stefaniuk et al. 2007) and gravimetric measurements (Łój et al. 2007).

The deep bore-holes Bańska IG-1, Bańska PGP-1, Bukowina Tatrzańska PGP-1, Biały Dunajec PGP-2, Biały Dunajec PAN-1 drill through the Podhale Flysch (Wieczorek \& Barbacki 1997, Chowaniec \& Kępińska 2003, Chowaniec 2009). Maruszyna IG-1 penetrated the PKB (Birkenmajer \& Gedl, 2012). 
Nowy Targ PIG-1 drilled in the Magura Nappe, Krynica Unit in the vicinity of the suture zone (Paul \& Poprawa 1992). Several bore-holes were drilled through the Outer Carpathian Flysch along the Zakopane - Kraków line (Figs. 2, 5). Deep boreholes Tokarnia IG-1, Trzebunia 2 and Głogoczów IG-1 reached the sedimentary cover of the North European Platform below the Outer Carpathian Nappes (Golonka et al. 2005).

Input data for this study come from four archival profiles $(24 \mathrm{~A}-5-87 \mathrm{~K}, 24-5-87 \mathrm{~K}, 26-5-87 \mathrm{~K}$ and $28-5-87 \mathrm{~K})$ generated in 1987 and reprocessed in 2015 by Geofizyka Kraków SA. The fieldwork was conducted along the seismic profiles and major tectonic zones.

Geological interpretation of seismic profiles requires well-to-seismic ties, which allow well data (measured in units of depth) to be compared to seismic data (measured in units of time). This procedure allows the correlation of geological boundaries identified in a well with specific reflection on the seismic section. For well-to-seismic ties, synthetic seismograms were used. Input data for the generation of synthetic seismograms (SS) are sonic logs (Vp) and bulk density logs
(RHOB) as well as gamma ray logs (GR) with lithology profile (LITHOLOGY). The Bańska IG-1 well, located on the south side of Pieniny Klippen Belt, penetrates the Podhale Flysch (Fig. 6), Maruszyna IG-1 which penetrated the PKB and Nowy Targ PIG-1 located on the north side of PKB and not penetrating the Magura nappe, were used for the correlation of seismic horizons on lines $26-5-87 \mathrm{~K}, 28-5-87 \mathrm{~K}, 24 \mathrm{~A}-5-87 \mathrm{~K}$ and $24-5-87 \mathrm{~K}$ (Figs. 7, 8). The observations in outcrops allowed the correlation of seismic units with geological formations.

For interpretation, alongside the original seismic sections seismic attributes were also derived and utilized: namely the amplitude envelope and instantaneous phase (Taner \& Sheriff 1977). The amplitude envelope facilitates the interpretation in the presence of strong reflections and in non-reflection zones. Intervals with strong reflections are associated with sedimentary rocks composed of high velocity beds (e.g. Subtatric or Fore-Magura units). Non-reflection zones can be interpreted as crystalline rocks. The instantaneous phase is independent of amplitude and shows the continuity and discontinuity of seismic events.

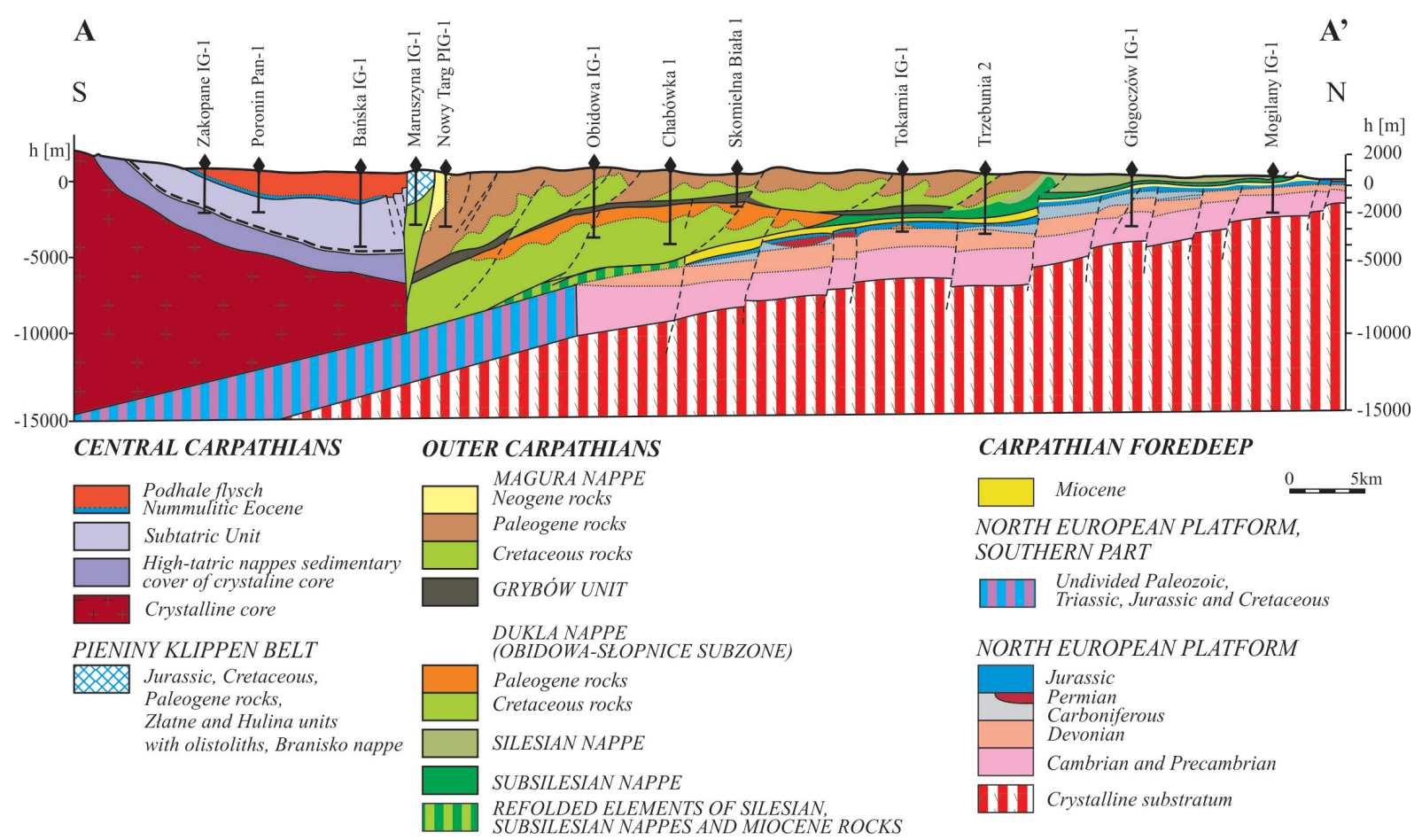

Fig. 5. Cross-section A-A' through the Western Carpathians between the Inner Carpathian Tatra Mountains and the Carpathian Foredeep (Zakopane - Kraków line, based on Cieszkowski in Golonka et al. 2005, modified according to Golonka et al. 2016a, 2016b, and the results of seismic profile 1). Cross-section location in Figure 2 
It was used for interpretation in zones with high amplitude variability. An apparent dip attribute shows the dip of seismic reflectors and its direction in regard to the strike of the seismic profile. It was used to distinguish areas of rapid dip changes in the zones of thrusts, faults, fold axes and olistoliths. Due to the absence of deep bore-holes, which are essential for the good geological interpretation of seismic horizons, the sometimes insufficient seismic quality and the necessity of the identification of complex tectonic boundaries on the basis of the variability of the seismic record, the interpretation in some parts is perhaps questionable. After interpretation, the seismic profiles were converted to depth domain with the application of smoothed NMO velocities. Stacking velocities were converted to average velocities and calibrated by wells (Fig. 6).

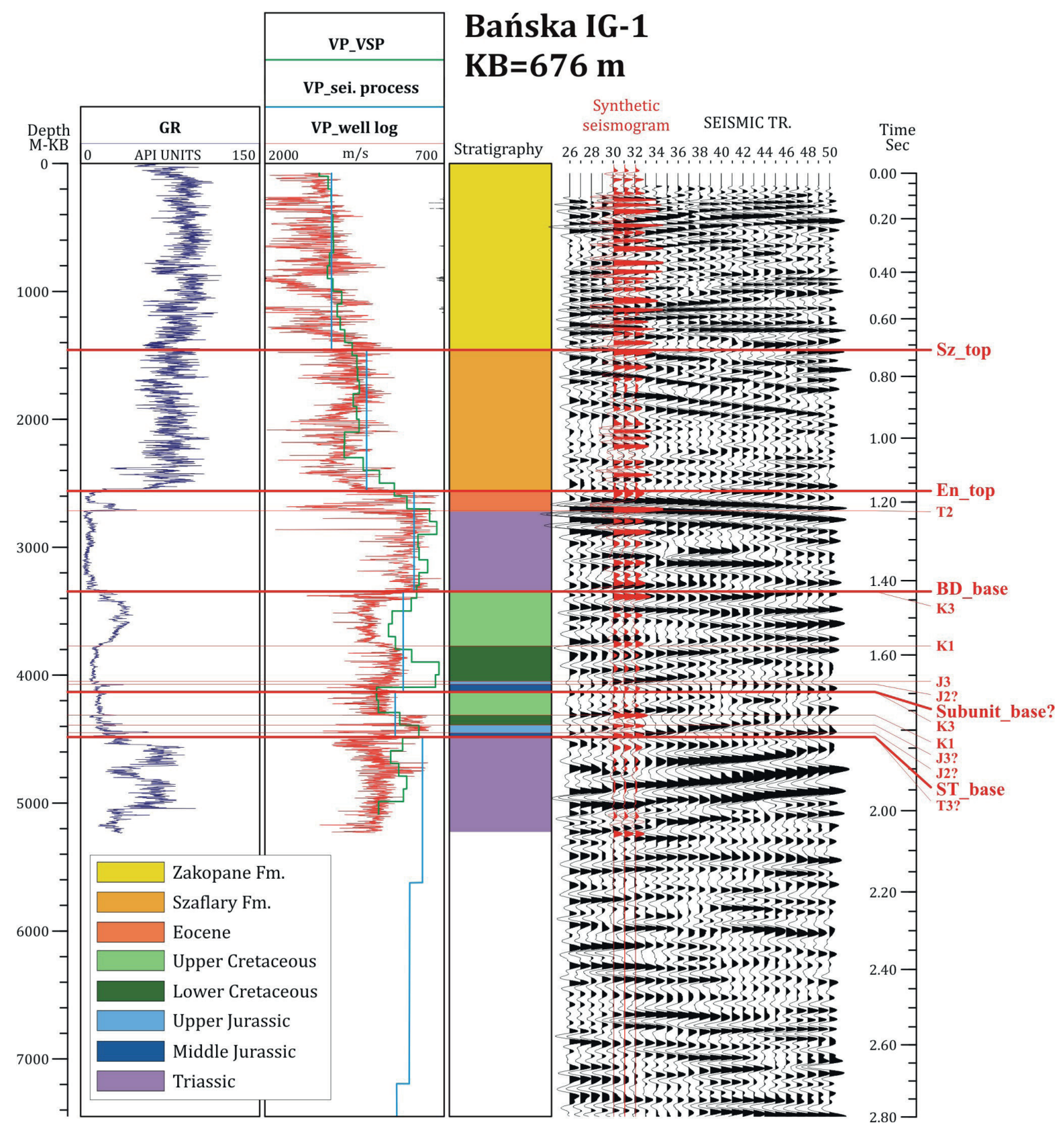

Fig. 6. Synthetic seismogram - Bańska IG-1: GR - gamma ray, VP_VSP - interval velocities from vertical seismic profiling, $V P \_w e l l ~ l o g-a c o u s t i c l o g, V P \_s e j . p r o c e s s$. - interval velocities from stacking process (calibration of time to depth conversion velocity model). Markers: Sz_top - top of the Szaflary Formation, En_top - top of the Eocene numulites limestone, BD_base base of the Biały Dunajec Unit, ST_base - base of the Subtatric Unit 


\section{RESULTS AND DISCUSSION}

Based on seismic and bore-hole data, the following structural units were recognized within the Central Carpathians: Podhale Flysch (Central Carpathian Paleogene), Subtatric Unit, High-Tatric Unit and crystalline Central Carpathian basement. The Zakopane Formation (surface Sz_top) and the Szaflary Formation (Sz_top En_top) were distinguished within the Podhale Flysch. The Subtatric Unit includes: Biały Dunajec (En_top - BD_base) and Bańska (BD_base - ST base) units. High-Tatric Unit includes: High-Tatric nappe (ST_base - HT_base) and High-Tatric autochthonous sedimentary cover (HT_base TC_top). Tatric Crystalline Basement (TC_top C_base) contains high reflection zone ( $\mathrm{HRz}$ _top HRz_base) (see Figs. 6-8)

The Szaflary Formation is heavily deformed and often vertical in the border zone near the $\mathrm{PKB}$, while dipping gently toward the center of the Podhale Basin (Golonka et al. 2005, Oszczypko et al. 2006, Ludwiniak 2010, Mastella et al. 2012). It is covered by younger shaly flysch strata of the Zakopane Formation. The Paleogene Podhale Flysch is cut by several north-dipping faults, parallel to the southern PKB_S fault. Several tectonic units (nappes) are visible below the Paleogene Podhale Flysch. These units dip gently, almost horizontally. The Subtatric nappes are represented by the Biały Dunajec Unit composed mainly of the Jurassic-Cretaceous rocks and the Bańska Unit composed mainly of the Triassic rocks. They are underlain by the High-Tatric units and non-reflective crystalline Tatric rocks (Figs. 5, 7).

The Pieniny Klippen Belt is limited by two parallel faults - northern PKB_N and southern PKB_S (Figs. 7, 8). They merge into a single subvertical fault. The Pieniny Klippen Belt forms strongly tectonized subvertical structure three kilometers wide including the Jurassic, Cretaceous, Paleogene and Neogene sedimentary sequences. Northvergent trust-sheets (nappes) are visible in analyzed profiles (Figs. 7, 8). The large Hulina Unit contains thrust-sheets observed in the surface geology as repeated sequences of the Upper Cenomanian-Coniacian variegated shales of the Malinowa Formation and the Maastrichtian-Paleocene sandstones of the Jarmuta Formation. The chaotic structural arrangement within these trust-sheets suggests the existence of olistoliths surrounded by flysch deposits (see Golonka et al. 2015). The southern flysch of the Złatne Unit is marked as a small sliver within analyzed seismic profile (Fig. 8). It crops out along the southern boundary of the PKB. The larger area, displaying the mélange character of this unit, is exposed on the Niedzica area and south of the Polish-Slovak border in the Haligovce area (Fig. 4) (Golonka et al. 2005, 2015, 2016a, 2016b, 2017). Several thrust sheets could be distinguished in these areas. These thrust-sheets were recognized as repeated sequences of flysch belonging to the Cretaceous Sromowce Formation as well as the Paleocene-Oligocene marls and flysch sequences with thick-bedded coarse-grained sandstones and conglomerates. The Zlatne Unit thrusts over the Hulina Unit in the Spisz Pieniny and the Małe Pieniny mountain ranges. The ridge, mainly Pieniny and Czertezik successions, crops out in the Pieniny Mountains between Czorsztyn and Szczawnica (Kulka et al. 1985, Golonka et al. 2005).

The Złatne Unit is composed of the Jurassic-Lower Cretaceous carbonates and radiolarites and the Albian-Neogene flysch and marls. The olistoliths in the Złatne Unit were transported from the southeastern margin of the Alpine Tethys and represent various parts of the Inner Carpathian terrane and its slopes. The huge Mesozoic Haligovce Klippen olistolith and the Paleocene limestone reef blocks crop out in the Małe Pieniny area in the eastern part of the investigated area (Golonka et al. 2015, 2017). The Hulina and Złatne units in Szaflary-Nowy Targ area and in the Spisz Pieniny Mountains unconformably cover the lower PKB units that resemble the Magura Nappe flysch (Figs. 7, 8) (Golonka et al. 2016a, 2016b). They are separated from the Krynica Unit of the Magura Nappe by the northern PKB_N fault. The Krynica Unit emerges as tectonic windows from the olistostrome type mélange of the Hulina Unit in the Małe Pieniny Mountains (Golonka \& Rączkowski 1984a, 1984b, Jurewicz 1994, 1997, Oszczypko \& Oszczypko-Clowes 2014).

The seismic boundaries in the suture zone north of the PKB were estimated on the basis of the seismic sections, 24-5-87K (Figs. 7, 8), the results of Nowy Targ PIG-1 bore-hole (Paul \& Poprawa 1992) as well as gravimetric and electric surveys (Pomianowski 2003). 


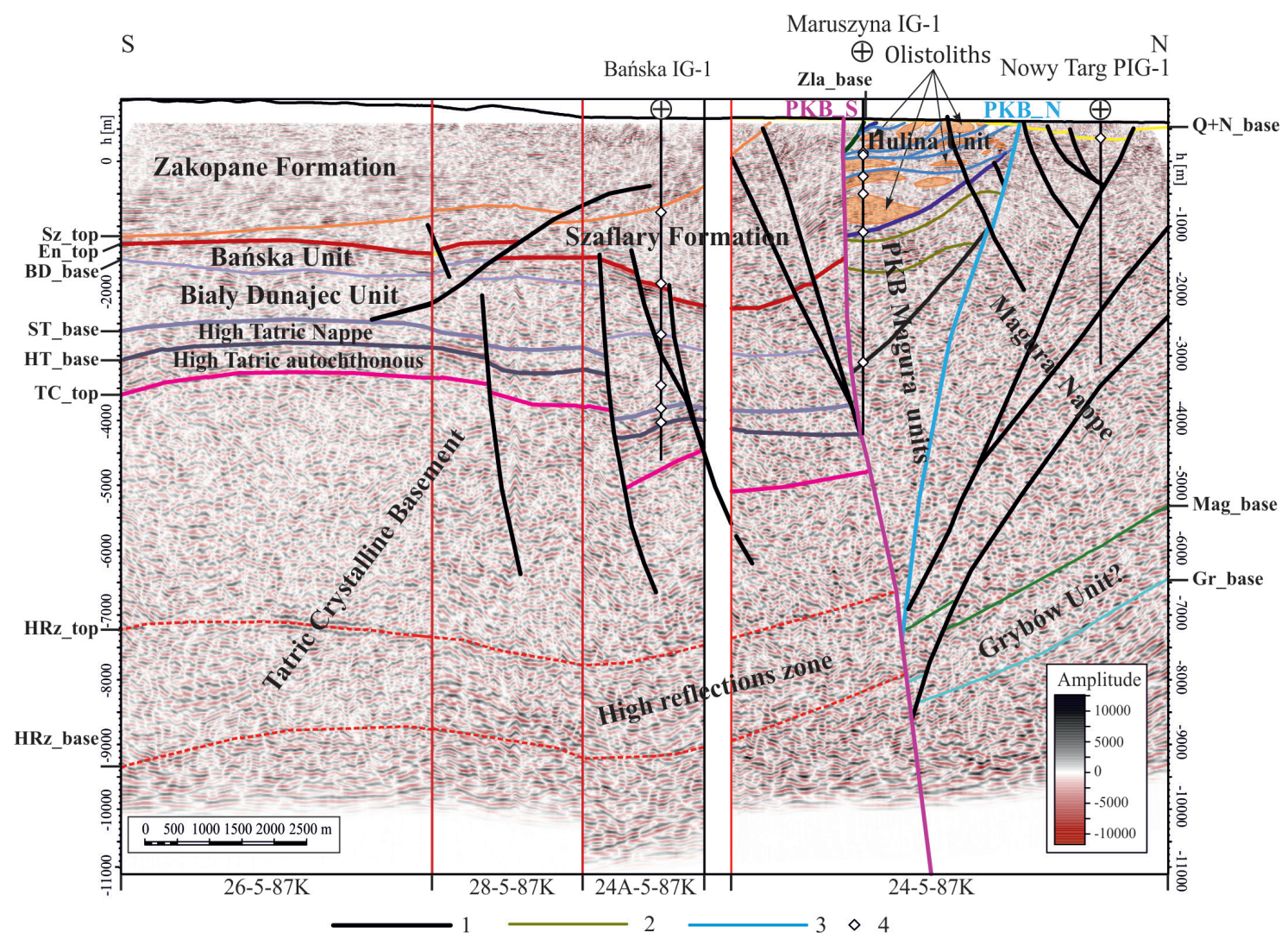

Fig. 7. Seismic profile 1 based on combined seismic lines 24-5-87K 28-5-87K and 26-5-87K: 1 - fold, 2 - seismic scale fault similar to Magura structures, 3 - PKB thrusts, 4 - lithostratigraphic and tectonic well markers

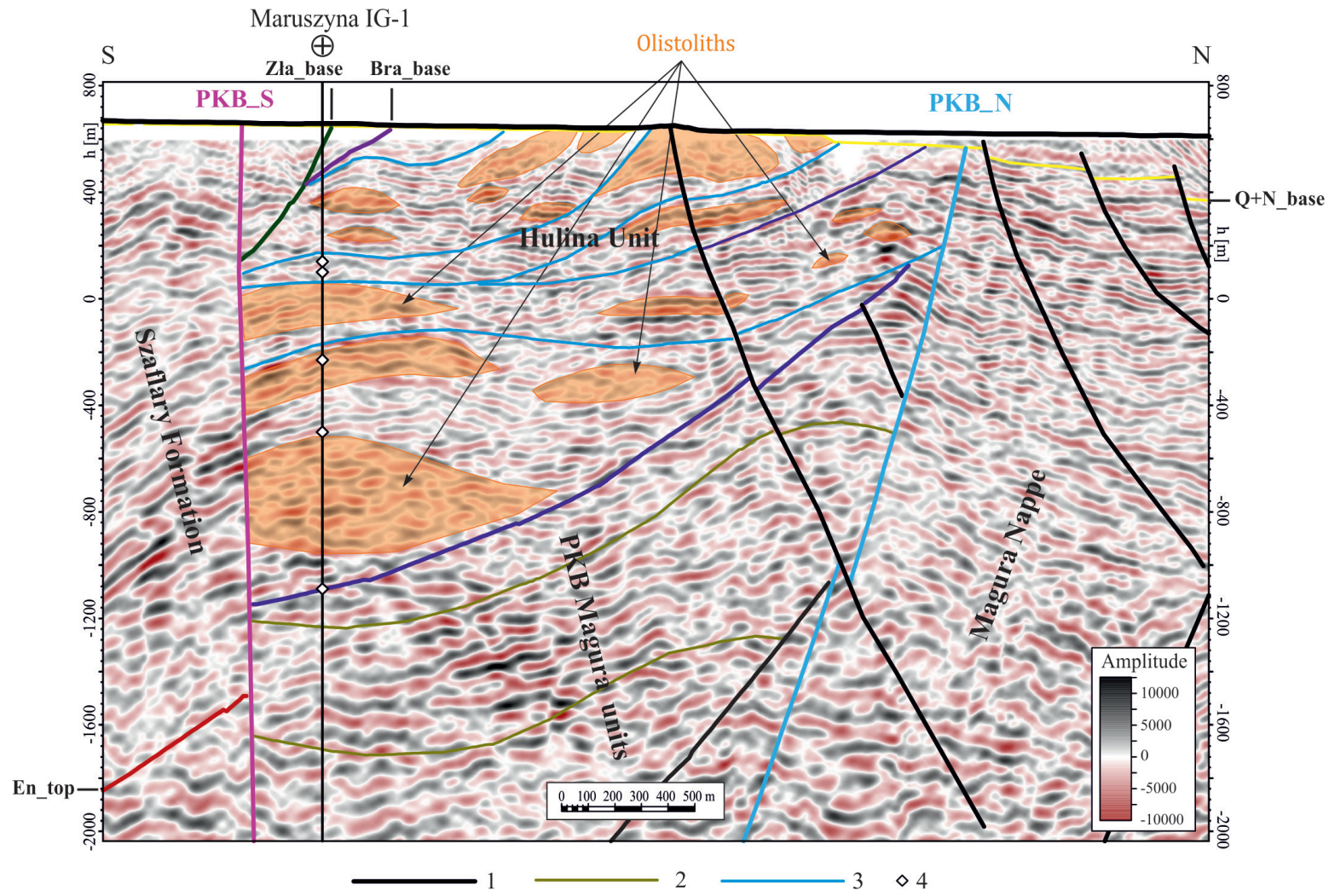

Fig. 8. Fragment of profile 1 enlarged. Legend as in Figure 7 
The following structural units were distinguished: Quaternary and Neogene deposits (surface - Q+N_base), Magura Nappe (Q+N_base - Mag_base) and Grybów Unit belonging to For-Magura group of nappes (units) (Mag_base - Gr _base (Gr _base - C_base). The Krynica Unit crops out along the northern PKB_N fault in the eastern part of the PKB in Poland (Golonka \& Rączkowski 1984a, 1984b, Kulka et al. 1985). In the western part, it is covered by the Quaternary and Neogene deposits. The Neogene rocks belong to the Orava-Nowy Targ Neogene Basin, which contains over $900 \mathrm{~m}$ of gravel, sand-silt and clay deposits in the Polish and Slovak Orava (Golonka et al. 2005 and references therein).

The Magura Nappe, Krynica Unit crops out along the PKB_N fault in the eastern part of the investigated area as well as north of the Quaternary and Neogene deposits in the vicinity of Nowy Targ. This unit was also encountered in the deep drillings Nowy Targ PIG-1 and Obidowa IG-1. The Fore-Magura group of nappes (units) was encountered in the Obidowa IG-1 and Chabówka 1. The Grybów and Obidowa-Słopnice units were distinguished in these wells (Ślączka et al. 2006). It belongs to the Dukla (our preference) or Skole Nappe. The Dukla (Obidowa-Słopnice) forms here the lowermost Outer Carpathian nappe or is underlain by the Silesian Nappe (Fig. 5). The great continental plate, known as the North European Platform, forms the basement of the Northern Carpathians. This plate consists of the Proterozoic, Vendian (Cadomian) and Lower Paleozoic (Caledonian) fragments, deformed and metamorphosed rocks. The Paleozoic, Mesozoic, Paleogene and Neogene strata cover the crystalline, metamorphosed basement (Golonka et al. 2011). The PKB marks the suture zone between the Central Carpathian Plate and the North European Platform (part of the North European Plate).

\section{CONCLUSIONS}

The Podhale Flysch (Central Carpathian Paleogene) rocks cover the Tatric units south of the PKB. The Subtatric as well as the High-Tatric, autochthonic and allochthonic rocks cover the Paleozoic Central Carpathian Basement belonging to the Central Carpathian Plate. The Polish part of the Pieniny Klippen Belt (PKB) marks the suture zone between the Central Carpathian Plate and the North European Platform (part of the North European Plate).

The PKB is limited by two parallel faults merging into a single subvertical fault. The PKB forms several north-vergent trust-sheets (nappes). The Albian-Neogene flysch sequences constitute the main component of the PKB in the survey zone. They contain olistoliths, which are mainly Jurassic-Early Cretaceous in age. The Jurassic-Lower Cretaceous rocks also form a tectonic unit in the Pieniny Mountains (the central part of the PKB in Poland). These rocks were deposited within the paleogeographic realm known as the Alpine Tethys.

The North European Platform, consisting of metamorphosed Proterozoic, Vendian (Cadomian) and Lower Paleozoic (Caledonian) fragments and covered by Paleozoic, Mesozoic, Paleogene and Neogene strata, forms the basement of the Northern Carpathians. The Paleozoic, Mesozoic, Paleogene and Neogene strata cover the Proterozoic crystalline, metamorphosed basement.

The allochthonous Outer Carpathians, consisting of several nappes (thrust-sheets) verging northward, are thrust over each other and over the North European Platform which is dips gently southward.

This research has been supported by the National Centre for Research and Development (NCBiR) grant no. BG2/ShaleCarp/14, National Science Centre (NCN) grant 2016/23/B/ST10/01896 as well as the AGH University of Science and Technology in Kraków grants no. 5.5.14.588, 11.11.140.005 and 11.11.140.645.

\section{REFERENCES}

Birkenmajer K., 1977. Jurassic and Cretaceous lithostratigraphic units of the Pieniny Klippen Belt, Carpathians, Poland. Studia Geologica Polonica, 45, 1-159.

Birkenmajer K., 1983. Uskoki przesuwcze w północnym obrzeżeniu pienińskiego pasa skałkowego w Polsce [Strike-slip faults in the northern boundary zone of the Pieniny Klippen Belt, Carpathians]. Studia Geologica Polonica, 77, 89-112. 
Birkenmajer K., 1986. Stages of structural evolution of the Pieniny Klippen Belt, Carpathians. Studia Geologica Polonica, 88, 7-32.

Birkenmajer K., 1988. Exotic Andrusov Ridge: its role in plate-tectonic evolution of the West Carpathian Foldbelt. Studia Geologica Polonica, 91, 7-37.

Birkenmajer K. \& Gedl P., 2012. Jurassic and Cretaceous strata in the Maruszyna IG-1 Deep Borehole (Pieniny Klippen Belt, Carpathians, Poland): lithostratigraphy, dinoflagellate cyst biostratigraphy, tectonics. Studia Geologica Polonica, 135, 7-54

Chowaniec J., 2009. Studium hydrogeologii zachodniej części Karpat polskich [Hydrogeology study of the western part of the Polish Carpathians]. Biuletyn Państwowego Instytutu Geologicznego, 734, 1-98.

Chowaniec J. \& Kępińska B., 2003. Podhale geothermal system - selected issues. [in:] Golonka J. \& Lewandowski M. (eds.), Geology, geophysics, geothermics and deep structure of the West Carpathians and their basement Publications of the Institute of Geophysics, Polish Academy of Sciences, Monographic Volume, 28 (363), Polish Academy of Sciences, 13-23.

Gawęda A. \& Golonka J., 2011. Variscan plate dynamics in the circum-carpathian area. Geodinamica Acta, 24, 3-4, 141-155.

Golonka J. \& Krobicki M., 2004. Jurassic paleogeography of the Pieniny and Outer Carpathian basins. Rivista Italiana di Paleontologia e Stratigrafia, 110, 5-14.

Golonka J. \& Rączkowski W., 1984a. Szczegółowa mapa geologiczna Polski 1:50 000. Arkusz Piwniczna. Wydawnictwa Geologiczne, Warszawa.

Golonka J. \& Rączkowski W., 1984b. Objaśnienia do szczegółowej mapy geologicznej Polski. Arkusz Piwniczna. Wydawnictwa Geologiczne, Warszawa.

Golonka J. \& Sikora W., 1981. Mikrofacje ścienionych sedymentacyjnie osadów pienińskiego pasa skałkowego w Polsce [Microfacies of the Jurassic and Lower Cretaceous sedimentarily thinned deposits of the Pieniny Klippen Belt in Poland]. Biuletyn Instytutu Geologicznego, 31, 7-37.

Golonka J. \& Waśkowska A., 2014. Paleogene of the Magura Nappe adjacent to the Pieniny Klippen Belt between Szczawnica and Krościenko (Outer Carpathians, Poland). Geology, Geophysics \& Environment, 40, 4, 359-376.

Golonka J., Aleksandrowski P., Aubrecht M., Chowaniec J., Chrustek M., Cieszkowski M., Florek R., Gawęda A., Jarosiński M., Kępińska B., Krobicki M., Lefeld J., Lewandowski M., Marko F., Michalik M., Oszczypko N., Picha F., Potfaj M., Słaby E., Ślączka A., Stefaniuk M., Uchman A. \& Żelaźniewicz A., 2005. Orava Deep Drilling Project and the Post Paleogene tectonics of the Carpathians. Annales Societatis Geologorum Poloniae, 75, 211-248.

Golonka J., Gahagan L., Krobicki M., Marko F., Oszczypko N. \& Ślączka A., 2006a. Plate Tectonic Evolution and Paleogeography of the Circum-Carpathian Region. [in:] Golonka J. \& Picha F. (eds.), The Carpathians and their foreland: Geology and hydrocarbon resources, American Association of Petroleum Geologists Memoir, 84, AAPG, 11-46.
Golonka J., Krobicki M., Oszczypko N. \& Salata D., 2006b. Stop 7. Krościenko-Zawiasy Klippe-Contact Zone between the Pieniny Klippen Belt and the Magura Nappe. Geolines, 20, 182-183.

Golonka J., Pietsch K. \& Marzec P., 2010. Thrusts, strikeslip faults, out-of-sequence thrusts and their expression in seismic survey in the Polish Outer Carpathians. [in:] Ludwiniak M., Konon A. \& Żylińska A. (eds.), CETeG 2010: $8^{\text {th }}$ meeting of the Central European Tectonic Group studies (CETeG): 22-25 April 2010, Machocice Kapitulne, Poland: conference proceedings, University of Warsaw, Faculty of Geology, Polish Geological Institute - National Research Institute, Warsaw, 66-67.

Golonka J., Pietsch K. \& Marzec P., 2011. Structure and plate tectonic evolution of the northern Outer Carpathians. [in:] Closson D. (ed.), Tectonics, INTECH, Rijeka, Croatia, 65-92.

Golonka J., Krobicki M., Waśkowska A., Cieszkowski M. \& Ślączka A., 2015. Olistostromes of the Pieniny Klippen Belt, Northern Carpathians. Geological Magazine, 152, 02, 269-286.

Golonka J, Pietsch K., Marzec P, Kasperska M., Dec J., Cichostępski K., Lasocki S. \& Orlecka-Sikora B., 2016a. Deep structure of the Pieniny Klippen Belt in Poland. [in:] Vojtko R. (ed.), CETeG 2016: $14^{\text {th }}$ meeting of the Central European Tectonic Groups, $21^{\text {th }}$ meeting of the Czech Tectonic Studies Group (ČTS): Predná Hora, Slovakia, April 28-May 1, 2016: abstract volume, Comenius University, Bratislava, Slovakia, 32.

Golonka J., Pietsch K., Marzec P., Kasperska M., Cichostępski K., Dec J., Lasocki S., Mirek J. \& Orlecka-Sikora B., 2016b. Central Carpathians - North European plates suture zone in Poland. [in:] Šujan M. (ed.), $10^{\text {th }}$ ESSEWECA conference: Environmental, Structural and Stratigraphical Evolution of the Western Carpathians: $1^{\text {st }}-2^{\text {nd }}$ December 2016, Bratislava, Slovakia: abstract book, The Publishing House of the Comenius University, Bratislava, 31-32.

Golonka J., Krobicki M., Waśkowska A., Cieszkowski M. \& Ślączka A., 2017. Reply. Discussion of 'Olistostromes of the Pieniny Klippen Belt, Northern Carpathians'. Geological Magazine, 154, 193-200.

Grad M., Guterch A., Keller G.R., Janik T., Hegedűs, E., Vozár J., Ślączka A., Tiira T. \& Yliniemi J., 2006 Lithospheric structure beneath trans-Carpathian transect from Precambrian platform to Pannonian basin: CELEBRATION 2000 seismic profile CEL05. Journal Geophysical Research, 111, B3301. DOI:10.1029/2005JB003647.

Hrubcová P. \& Środa P., 2015. Complex local Moho topography in the Western Carpathians: Indication of the ALCAPA and the European Plate contact. Tectonophysics, $638,63-81$.

Janik T., Grad M., Guterch A. \& Celebration 2000 Working Group., 2009. Seismic structure of the lithosphere between the East European Craton and the Carpathians from the net of Cellebration 2000 profiles in SE Poland. Geological Quarterly, 53, 1, 141-158.

Janik T., Grad M., Guterch A., Vozár J., Bielik M., Vozárova A., Hegedus E., Attila Kovács C. \& Kovác I., 2011. Crustal structure of the Western Carpathians and Pannonian Basin System: Seismic models from CELEBRATION 2000 data and geological implication. Journal of Geodynamics, 52, 2, 97-113. 
Jurewicz E., 1994. Structural analysis of the Pieniny Klippen Belt at Jaworki, Carpathians, Poland. Studia Geologica Polonica, 106, 7-87.

Jurewicz E., 1997. The contact between the Pieniny Klippen Belt and Magura Unit (the Małe Pieniny Mts.). Geological Quarterly, 41, 315-326.

Jurewicz E., 2005. Geodynamic evolution of the Tatra Mts. and the Pieniny Klippen Belt (Western Carpathians): problems and comments. Acta Geologica Polonica, 55, 295-338.

Kaczmarek A., Oszczypko-Clowes M. \& Cieszkowski M., 2016. Early Miocene age of Stare Bystre Formation (Magura Nappe, Outer Carpathians, Poland) indicated by the calcareous nannoplankton. Geological Quarterly, 60, 2, 341-354

Kováč M., Nagymarosy A., Oszczypko N., Ślączka A., Csontos L., Marunteanu M., Matenco L. \& Márton M., 1998. Palinspastic reconstruction of the Carpathian-Pannonian region during the Miocene. [in:] Rakús M. (ed.), Geodynamic development of the Western Carpathians, Dionýz Štúr Publishers, Geological Survey of Slovac Republic, Bratislava, 189-217.

Krobicki M. \& Golonka J., 2008. Geological history of the Pieniny Klippen Belt and Middle Jurassica black shales as one of the oldest deposits of this region - stratigraphical position and palaeoenvironmental significance. Geoturystyka, 2, 13, 3-18.

Kulka A., Rączkowski W., Żytko K. \& Paul Z., 1985. Szczegółowa mapa geologiczna Polski. 1:50 000. Arkusz Szczawnica-Krościenko. Państwowy Instytut Geologiczny, Wydawnictwa Geologiczne, Warszawa.

Ludwiniak M., 2010. Multi-stage development of the joint network in the flysch rocks of western Podhale (Inner Western Carpathians, Poland). Acta Geologica Polonica, 60, 283-316.

Łój M., Madej J., Porzucek S. \& Zuchiewicz W., 2007, Periodic gravity changes in the young tectonic movement investigation of selected area in the Polish Western Carpathians. Acta Geodynamica et Geomaterialia, 4, 4, 97-107.

Mahel M., 1974. The Inner Carpathians. [in:] Mahel M. (ed.), Tectonics of the Carpathian-Balkan Regions, Geologický Ústav Dionyza Štura, Bratislava, 91-133.

Mastella L., Ludwiniak M. \& Klimkiewicz D., 2012. Budowa geologiczna doliny Białego Dunajca. Przegląd Geologicz$n y, 60,496-505$.

Oszczypko N. \& Oszczypko-Clowes M., 2014. Geological structure and evolution of the Pieniny Klippen Belt to the east of the Dunajec River - a new approach (Outer Western Carpathians, Poland). Geological Quarterly, 58, 737-758.

Oszczypko N., Golonka J., Cieszkowski M., Krobicki M., Oszczypko-Clowes M. \& Salata D., 2006. Conference excursion 2: Late Cretaceous-Neogene evolution of the Polish Carpathians. Geolines, 20, 165-186.

Paul Z. \& Poprawa D., 1992. Budowa geologiczna płaszczowiny magurskiej w strefie przypienińskiej w świetle wyników badań uzyskanych z wiercenia Nowy Targ PIG1. Przegląd Geologiczny, 40, 404-409.

Pomianowski P., 2003. Tektonika Kotliny Orawsko-Nowotarskiej - wyniki kompleksowej analizy danych grawimetrycznych i geoelektrycznych [Tectonics of the Orava-Nowy Targ Basin - results of the combined analysis of the gravity and geoelectrical data]. Przeglad Geologiczny, 51, 6, 498-506.

Stefaniuk M., Klityński W., Jarzyna J. \& Golonka, J., 2007. Struktura nasunięcia Karpackiego i jego podłoża w polskich Karpatach Zachodnich w świetle reinterpretacji wybranych profili magnetotellurycznych [The structure of the Carpathian overthrust and its basement in the Polish Western Carpathians in the light of reinterpretation of selected regional magnetotelluric profiles]. Geologia - kwartalnik Akademii Górniczo-Hutniczej im. Stanisława Staszica w Krakowie, 33, 143-166.

Ślączka A., Kruglow S., Golonka J. Oszczypko N. \& Popadyuk I., 2006. The General Geology of the Outer Carpathians, Poland, Slovakia, and Ukraine. [in:] Golonka J. \& Picha F. (eds.), The Carpathians and their foreland: Geology and hydrocarbon resources, American Association of Petroleum Geologists Memoir, 84, AAPG, 221-258.

Środa P., Czuba W., Grad M., Guterch A., Tokarski A.K., Janik T., Rauch M., Keller G.R. Hegedüs E., Vozár J. \& CELEBRATION 2000 Working Group, 2006. Crustal and upper mantle structure of the Western Carpathians from CELEBRATION 2000 profiles CEL01 and CEL04: seismic models and geological implications. Geophysical Journal International, 167, 737-760.

Taner M.T. \& Sheriff R.E., 1977. Application of Amplitude, Frequency, and Other Attributes to Stratigraphic and Hydrocarbon Determination. American Association of Petroleum Geologists Memoir, 26, AAPG.

Wieczorek J. \& Barbacki A., 1997 Przekrój geologiczny przez nieckę podhalańską i jej podłoże na podstawie danych sejsmicznych i wiertniczych; implikacje dla geotermii. Przeglad Geologiczny, 45, 7, 715-720. 